\title{
The Effect of COVID-19 Pandemic on Depression, Anxiety and Stress Levels of Pregnant Women
}

\section{Hamile Kadınlarda COVID-19 Pandemisinin Depresyon, Anksiyete ve Stres Düzeyleri Üzerine Etkisi}

\section{(D) Elif Çiler Eren1, (D) Sevda Gümüşs Şanlı²}

${ }^{1}$ Medipol University Faculty of Medicine, Department of Obstetrics and Gynecology, İstanbul, Turkey

2Medipol University Faculty of Medicine, Department of Psychiatry, İstanbul, Turkey

\section{Abstract}

Objective: Coronavirus disease-2019 (COVID-19) pandemic has negatively affected the psychology of the society. In this study, it was aimed to determine the stress, anxiety and depression levels in pregnant women during the COVID-19 pandemic and to investigate the delivery method attitudes using various scales.

Method: The study included 151 pregnant women admitted to the obstetrics and gynecology clinic of our tertiary hospital for follow-up. A 31-question questionnaire containing demographic information and questions about COVID-19, impact of event scale (IES-R), depression anxiety stress scale-21 (DASS-21) and revised pregnancy-related anxiety questionnaire-revised (PRAQ-R) scales were applied.

Results: According to the classifications made in DASS-21 subgroups, $16.5 \%$ of the pregnant women had severe or extreme depression, $35.1 \%$ had severe or extreme anxiety, $11.2 \%$ had severe or extreme stress level. The mean IES-R and PRAQ-R scores were found to be significantly higher in those under 35 years of age than those aged 35 years and over ( $p=0.02$ and $p=0.01$, respectively). PRAQ-R $(p<0.001)$, DASS-21 total $(p=0.019)$, DASS-21 anxiety $(p=0.012)$ and DASS-21 stress $(p=0.014)$ scores were significantly higher in those who had their first pregnancy compared to experienced pregnant women.

Conclusion: In the present study, it was determined that the pandemic had a negative effect on the depression, anxiety and stress levels of pregnant women, and this effect was higher especially in younger pregnant women and in those experiencing their first pregnancy.

Keywords: Anxiety, COVID-19, depression, pandemic, pregnancy

\section{Öz}

Amaç: Koronavirüs hastalığı-2019 (COVID-19) salgını toplumun psikolojisini olumsuz etkilemiştir. Bu çalışmada, gebelerde COVID-19 salgını sırasında yaşanan stres, anksiyete ve depresyon düzeylerinin belirlenmesi ve çeşitli ölçeklerle doğum yöntemi tutumlarının incelenmesi amaçlanmıştır.

Yöntem: Çalışmaya üçüncü basamak hastanemizin kadın hastalıkları ve doğum kliniğine takip için başvuran 151 gebe dahil edildi. Gebelerin hepsine demografik bilgilerini içeren ve COVID-19, olay etkisi ölçeği (IES-R), depresyon anksiyetesi stres ölçeği-21 (DASS-21) ve gözden geçirilmiş gebelikle ilgili anksiyete anketi (PRAQ-R) ile ilgili soruları içeren 31 soruluk bir anket uygulandı.

Bulgular: DASS-21 alt gruplarında yapılan sınıflandırmalara göre, gebelerin $\% 16,5^{\prime} i$ şiddetli veya aşır depresyon, \%35,1'i şiddetli veya aşıı anksiyete, \%11,2'si şiddetli veya aşırı stres düzeyine sahipti. Otuz beş yaşın altındakilerde ortalama IES-R ve PRAQ-R puanları 35 yaş ve üzerindekilere göre anlamlı derecede yüksek bulundu (sırasıyla $p=0,02$ ve $p=0,01)$. Illk defa hamile olanlarda PRAQ-R $(p<0,001)$, DASS-21 toplam $(p=0,019)$, DASS-21 anksiyete $(p=0,012)$ ve DASS-21 stres $(p=0,014)$ puanları daha önce gebelik geçiren kadınlara göre yüksekti.

Sonuç: Bu çalışmada, salgının gebelerin depresyon, anksiyete ve stres düzeylerini olumsuz etkilediği, bu etkinin özellikle genç gebelerde ve ilk gebeliğini yaşayanlarda daha da yüksek olduğu tespit edilmiştir.

Anahtar kelimeler: Anksiyete, COVID-19, depresyon, hamilelik, pandemi

Address for Correspondence: Elif Çiler Eren, Medipol University Faculty of Medicine, Department of Obstetrics and Gynecology, İstanbul, Turkey E-mail: dreliferen@hotmail.com ORCID: orcid.org/0000-0002-1535-5934 Received: 20.04.2021 Accepted: 12.08.2021

Cite this article as: Çiler Eren E, Gümüş Şanlı S. The Effect of COVID-19 Pandemic on Depression, Anxiety and Stress Levels of Pregnant Women. Bagcilar Med Bull 2021;6(3):306-313

๑) Copyright 2021 by the Health Sciences University Turkey, Bagcilar Training and Research Hospital Bagcilar Medical Bulletin published by Galenos Publishing House. 


\section{Introduction}

Pregnancy is a condition in which psychological sensitivity increases due to many hormonal and physiological factors. The threshold value for psychological disorders may decrease and abnormal psychological conditions can be seen more frequently in pregnancy $(1,2)$. Psychological disorders that can be seen during pregnancy can mostly be well tolerated. However, in some cases, the excessive increase of the level of these disorders can lead to adverse situations and complications for the pregnant woman, pregnancy and the baby. Therefore, the psychological status of pregnant women should be closely followed up (1-3).

Various scales have been created to determine the psychological conditions, the presence of stress, anxiety and depression, and their levels in pregnant women (4). Some of these scales measure the psychological effects of environmental events on pregnant women, while others only determine the levels of anxiety about pregnancy and baby. The mental state of a pregnant determined by these scales can provide the necessary precautions to be taken more appropriately and early and an appropriate rehabilitation program to be implemented $(4,5)$.

Coronavirus disease-2019 (COVID-19), known as the new coronavirus disease, has caused a major pandemic in 2020 and 2021. The COVID-19 pandemic has negatively affected the psychology of the pregnant women (6). In this study, it was aimed to determine the stress, anxiety and depression levels of pregnant women during the COVID-19 pandemic using various scales.

\section{Materials and Methods}

Approval was obtained from the University of Medipol Ethics Committee for non-interventional clinical trials within our institution (date: 02.01.2020; number: 001212). It was made with the permission of the Ministry of Health (2020-05-19T13_03_28). Written informed consent was obtained from all participants.

\section{Patients}

The study included 151 pregnant women who were admitted to the gynecology and obstetrics clinic of our tertiary care hospital for follow-up purposes and who had no health problems. Pregnant women who developed pregnancy-related complications, who had a previous history of psychiatric disease, and who had a history of a chronic disease were excluded from the study. All of these 151 patients were followed by the same author until the end of pregnancy.
Some scales have been developed to determine the levels of anxiety and depression in pregnant women. While these scales may have some advantages over each other, they may also have some shortcomings (7). Therefore, four separate scales were used in the present study and the effects of COVID-19 on pregnant women were tried to be determined from different aspects. A survey of 31 questions including demographic information and questions about COVID-19, impact of event scale (IES-R), depression anxiety stress scale-21 (DASS-21) and revised pregnancy-related anxiety questionnaire-revised (PRAQ-R) scales were applied to all participants. The scales were evaluated and analyzed by an experienced psychiatrist.

\section{IES-R}

IES-R is a scale that defines trauma-related psychological effects. It consists of 22 questions in total and is scored as never (0), a little (1), more or less (2), quite (3), and extreme (4). In this study, the main event was identified as the COVID-19 pandemic and questions were asked. Higher score means higher level of exposure $(5,8)$.

Scores are classified as follows:

24-32: Those with these high scores, who do not have full post-traumatic stress disorder (PTSD), will have partial PTSD or at least some of the symptoms (9).

33-38: This represents the best cutoff for a probable diagnosis of PTSD (10).

39 and above: This is high enough to suppress your immune system's functioning (even 10 years after an impact event) (11).

\section{DASS-21}

DASS-21 is a questionnaire consisting of 21 questions about depression, anxiety and stress. The questions are scored as never (0), sometimes or occasionally (1), quite often (2) and always (3). Accordingly, each category was classified as normal, mild, moderate, severe and extreme $(7,12)$. "Severe" was evaluated as 11 points and above in the depression subscale, as 8 points and above in the anxiety subscale, and as 13 points and above in the stress subscale.

\section{PRAQ-R}

PRAQ- $R$ is a questionnaire consisting of 10 questions determining the anxiety levels of pregnant women related to pregnancy, birth and baby. The questions are scored as "strongly disagree" (1), "disagree" (2), "slightly agree" (3), "agree" (4) and "strongly agree" (5). The score can be between 10 and 50 points. Higher score means higher level of exposure $(13,14)$. 


\section{Statistical Analysis}

All statistical analyses in the study were done using SPSS 25.0 software (IBM SPSS, Chicago, IL, USA). Descriptive data were given as numbers and percentages. In terms of categorical variables, comparisons between groups were made with the Pearson's chi-square test and Fisher's Exact test. Whether continuous variables were suitable for normal distribution was confirmed by the KolmogorovSmirnov test. The differences between the groups in terms of continuous variables were analyzed using the Student's t-test, and the comparison of mean values between multiple groups by variance analysis. The relationship between continuous variables was tested using the Spearman's correlation analysis. The results were evaluated within the $95 \%$ confidence interval, and $\mathrm{p}<0.05$ values were considered significant. Bonferroni correction was made where appropriate.

\section{Results}

The median age of the pregnant women included in the study was 30 years (22-44 years, minimum-maximum). A total of 129 women were under the age of 35 years, and 22 of them were 35 years old or older. The median week of gestation in women was 28 weeks (10-39 weeks, minimummaximum) (Table 1).

In women, the mean total IES-R score was $24.9 \pm 12.2$, the mean total PRAQ-R score was 27.4 \pm 7.4 , the mean total DASS-21 score was $9.7 \pm 7.7$. Among the DASS-21 subgroups, the mean depression score was $2.8 \pm 2.8$, the anxiety score was $2.8 \pm 2.6$, and the stress score was $4.1 \pm 3.2$ (Table 1).

\begin{tabular}{|c|c|c|c|c|}
\hline & Mean & SD & Minimum & Maximum \\
\hline Age (years) & $\begin{array}{l}30 \\
\text { (Median) }\end{array}$ & - & 22 & 44 \\
\hline $\begin{array}{l}\text { Pregnancy week } \\
\text { (week) }\end{array}$ & $\begin{array}{l}28 \\
\text { (Median) }\end{array}$ & - & 10 & 39 \\
\hline IES-R & 24.9 & 12.2 & 0 & 53 \\
\hline PRAQ-R & 27.4 & 7.4 & 11 & 49 \\
\hline DASS-21 & 9.7 & 7.7 & 0 & 38 \\
\hline $\begin{array}{l}\text { DASS-21 } \\
\text { depression score }\end{array}$ & 2.8 & 2.8 & 0 & 15 \\
\hline $\begin{array}{l}\text { DASS-21 anxiety } \\
\text { score }\end{array}$ & 2.8 & 2.6 & 0 & 11 \\
\hline $\begin{array}{l}\text { DASS-21 stress } \\
\text { score }\end{array}$ & 4.1 & 3.2 & 0 & 13 \\
\hline
\end{tabular}

IES-R: Impact of events scale, PRAQ-R: Pregnancy-related anxiety questionnaire, DASS-21: Depression anxiety stress scale-21, SD: Standard deviation
A total of $72.8 \%$ of the women had a university or higher education, $57 \%$ were working in a paid job. According to the classifications made in DASS- 21 subgroups, $16.5 \%$ of the pregnant women had severe or extreme depression, $35.1 \%$ had severe or extreme anxiety, $11.2 \%$ had severe or extreme stress level. The rate of pregnant women who changed hospitals or physicians due to COVID-19 was $21.2 \%$ (Table 2).

The mean IES-R and PRAQ-R scores were found to be significantly higher in those under 35 years of age than those aged 35 years and over ( $\mathrm{p}=0.02$ and $\mathrm{p}=0.01$, respectively). There was no difference in scale scores between the group with a family diagnosed with COVID-19 and the group with no relatives with COVID-19. DASS-21 ( $\mathrm{p}=0.019)$, PRAQ- $\mathrm{R}$ $(\mathrm{p}<0.001)$, DASS- 21 anxiety $(\mathrm{p}=0.012)$ and DASS-21 stress $(\mathrm{p}=0.014)$ scores were significantly higher in those who were experiencing their first pregnancy (Table 3).

There was no significant difference between education and job groups in terms of scale scores. PRAQ-R score was significantly higher in those living on minimum wage compared to other groups ( $\mathrm{p}=0.011$ ). The IES-R and DASS21 scores were significantly lower in those who said they had sufficient or fair knowledge about COVID-19 than those who said they had little or moderate knowledge $(\mathrm{p}=0.022$ and $\mathrm{p}=0.001$, respectively) (Table 4 ).

Scale scores were found to be significantly correlated with each other in correlation analysis. Week of gestation was significantly correlated only with the IES-R score $(\mathrm{p}=0.016$; $\mathrm{r}=0.185$ ) (Table 5).

It was seen that the highest scores in the IES-R scale belonged to the perceptions about the pandemic, the DASS-21 scale to the unreasonable fears, and the PRAQ-R scale to the questions about pain, birth and baby's health. According to all scales, the anxiety about a possible harm to the baby and not getting medical help were found to be significant during the pandemic period (Table 6).

\section{Discussion}

In this study, it was determined that the pandemic had a negative effect on the depression, anxiety and stress levels of pregnant women, and this effect was higher especially in younger pregnant women and in those experiencing their first pregnancy. Therefore, women who are thinking of pregnancy during the pandemic process should be given information about the effects of the COVID-19 virus on pregnancy and support should be provided to reduce anxiety. 
Table 2. Distributions of some variables and DASS-21 subgroups

n

$\%$

\begin{tabular}{|c|c|c|}
\hline \multicolumn{3}{|l|}{ Education status } \\
\hline Primary school & 9 & 6.0 \\
\hline High school & 32 & 21.2 \\
\hline University & 100 & 66.2 \\
\hline Postgraduate & 8 & 5.3 \\
\hline Doctorate & 2 & 1.3 \\
\hline \multicolumn{3}{|l|}{ Working condition } \\
\hline Self employed & 8 & 5.3 \\
\hline Paid employee & 78 & 51.7 \\
\hline Not working & 65 & 43.0 \\
\hline COVID-19 in the family & 10 & 6.6 \\
\hline Changing physician/hospital due to COVID-19 & 32 & 21.2 \\
\hline \multicolumn{3}{|l|}{ Anxiety of getting COVID-19 } \\
\hline Extreme & 4 & 2.6 \\
\hline Very & 10 & 6.6 \\
\hline Moderate & 73 & 48.3 \\
\hline Little & 47 & 31.1 \\
\hline None & 17 & 11.3 \\
\hline \multicolumn{3}{|l|}{ Anxiety about harm to the baby } \\
\hline Extreme & 18 & 11.9 \\
\hline Very & 43 & 28.5 \\
\hline Moderate & 55 & 36.4 \\
\hline Little & 25 & 16.6 \\
\hline None & 10 & 6.6 \\
\hline DASS-21 subgroups & $\mathbf{n}$ & $\%$ \\
\hline \multicolumn{3}{|l|}{ DASS-21 depression } \\
\hline Extreme & 12 & 7.9 \\
\hline Severe & 13 & 8.6 \\
\hline Moderate & 28 & 18.5 \\
\hline Mild & 29 & 19.2 \\
\hline Normal & 69 & 45.7 \\
\hline \multicolumn{3}{|l|}{ DASS-21 anxiety } \\
\hline Extreme & 32 & 21.2 \\
\hline Severe & 21 & 13.9 \\
\hline Moderate & 28 & 18.5 \\
\hline Mild & 21 & 13.9 \\
\hline Normal & 49 & 32.5 \\
\hline \multicolumn{3}{|l|}{ DASS-21 stress } \\
\hline Extreme & 7 & 4.6 \\
\hline Severe & 10 & 6.6 \\
\hline Moderate & 27 & 17.9 \\
\hline Mild & 14 & 9.3 \\
\hline Normal & 93 & 61.6 \\
\hline
\end{tabular}

DASS-21: Depression anxiety stress scale-21, COVID-19: Coronavirus disease-2019
Table 3. Comparisons between mean score percentages according to some variables

\begin{tabular}{|c|c|c|c|}
\hline & \multicolumn{2}{|l|}{ Age } & \multirow[t]{2}{*}{$\mathbf{p}$} \\
\hline & $<35$ years & $\geq 35$ years & \\
\hline IES-R & $25.9 \pm 11.5$ & $19.4 \pm 14.2$ & 0.020 \\
\hline PRAQ-R & $28.1 \pm 7$ & $23.7 \pm 9.1$ & 0.010 \\
\hline DASS-21 & $9.9 \pm 7.7$ & $7.5 \pm 7.4$ & 0.166 \\
\hline $\begin{array}{l}\text { DASS-21 depression score } \\
\text { (\%) }\end{array}$ & $6 \pm 5$ & $4.9 \pm 5.1$ & 0.346 \\
\hline DASS-21 anxiety score (\%) & $6.8 \pm 5.5$ & $5.1 \pm 5.2$ & 0.164 \\
\hline \multirow[t]{3}{*}{ DASS-21 stress score (\%) } & $7 \pm 5.3$ & $4.9 \pm 4.8$ & 0.088 \\
\hline & \multicolumn{2}{|c|}{ COVID-19 in the family } & \multirow[t]{2}{*}{$\mathbf{p}$} \\
\hline & Present & Absent & \\
\hline IES-R & $23.4 \pm 12.2$ & $25.1 \pm 12.2$ & 0.675 \\
\hline PRAQ-R & $29.6 \pm 5.3$ & $27.3 \pm 7.6$ & 0.356 \\
\hline DASS-21 & $12.4 \pm 6.8$ & $9.3 \pm 7.7$ & 0.224 \\
\hline $\begin{array}{l}\text { DASS-21 depression score } \\
(\%)\end{array}$ & $7.2 \pm 4.4$ & $5.7 \pm 5$ & 0.376 \\
\hline DASS-21 anxiety score (\%) & $8.9 \pm 4.4$ & $6.4 \pm 5.5$ & 0.164 \\
\hline \multirow[t]{3}{*}{ DASS-21 stress score (\%) } & $8.7 \pm 5.2$ & $6.5 \pm 5.2$ & 0.208 \\
\hline & \multicolumn{2}{|l|}{ Parity } & \multirow[t]{2}{*}{$\mathbf{p}$} \\
\hline & $0-1$ & $2-4$ & \\
\hline IES-R & $26.7 \pm 12.5$ & $23.6 \pm 11.8$ & 0.124 \\
\hline PRAQ-R & $30.1 \pm 7$ & $25.5 \pm 7.2$ & $<0.001$ \\
\hline DASS-21 & $11.2 \pm 8.4$ & $8.3 \pm 6.8$ & 0.019 \\
\hline $\begin{array}{l}\text { DASS-21 depression score } \\
(\%)\end{array}$ & $6.7 \pm 5.4$ & $5.2 \pm 4.6$ & 0.064 \\
\hline DASS-21 anxiety score (\%) & $7.8 \pm 6$ & $5.6 \pm 4.8$ & 0.012 \\
\hline DASS-21 stress score (\%) & $7.9 \pm 5.7$ & $5.8 \pm 4.7$ & 0.014 \\
\hline
\end{tabular}

Independent samples t-test was used. IES-R: Impact of events scale, PRAQ-R: Pregnancy-related anxiety questionnaire, DASS-21: Depression anxiety stress scale-21, COVID-19: Coronavirus disease-2019

The COVID-19 pandemic has been a major public issue in terms of mental health (15). In a large-scale study, it was found that during the COVID-19 pandemic, pregnant women showed a significantly higher rate of depression and anxiety symptoms, dissociative symptoms, and PTSD symptoms compared to pregnant women before COVID-19 (16). Studies have reported that the level of depression and anxiety in pregnant women increased significantly during the COVID-19 pandemic (17-19). In this study, the mean IES-R, DASS-21 and PRAQ-R scores in women show that the COVID-19 pandemic causes an increase in anxiety, depression and stress levels in pregnant women. However, the fact that the PRAQ-R scale score is much higher than the other survey scores means that the pregnant women are in a state of stress associated with their pregnancy rather than anxiety against COVID-19. All these findings show 
Table 4. Comparisons between mean score percentages by variables (mean \pm SD)

\begin{tabular}{|c|c|c|c|c|}
\hline & & IES-R & PRAQ-R & DASS-21 \\
\hline Education level & $\mathbf{p}$ & 0.735 & 0.706 & 0.308 \\
\hline Primary/high school & & $25.5 \pm 10.9$ & $27.1 \pm 8$ & $8.5 \pm 6.1$ \\
\hline University or higher & & $24.8 \pm 12.6$ & $27.6 \pm 7.3$ & $9.9 \pm 8.2$ \\
\hline $\begin{array}{l}\text { Income level (5 } \\
\text { groups) }\end{array}$ & $\mathbf{p}$ & 0.942 & $0.011 *$ & 0.724 \\
\hline Working status & $\mathbf{p}$ & 0.615 & 0.16 & 0.12 \\
\hline Self employed & & $22.3 \pm 8.3$ & $26.1 \pm 7.8$ & $5.7 \pm 4.4$ \\
\hline Paid employee & & $24.4 \pm 12.2$ & $28.7 \pm 8$ & $10.6 \pm 8.6$ \\
\hline Not working & & $25.9 \pm 12.6$ & $26.3 \pm 6.7$ & $8.9 \pm 6.6$ \\
\hline Knowledge level & $\mathbf{p}$ & 0.022 & 0.099 & 0.001 \\
\hline Little/moderate & & $28.6 \pm 12.3$ & $29.2 \pm 7.1$ & $12.2 \pm 7.4$ \\
\hline Sufficient/quite & & $23.6 \pm 11.8$ & $26.9 \pm 7.5$ & $8.5 \pm 7.5$ \\
\hline
\end{tabular}

One-Way ANOVA method was used. *Higher in the minimum wage group compared to other groups. IES-R: Impact of events scale, PRAQ-R: Pregnancyrelated anxiety questionnaire, DASS-21: Depression anxiety stress scale-21, SD: Standard deviation

Table 5. Correlation analysis between gestational week and scale total scores

Gestational IES-R DASS-21

week

\begin{tabular}{lllll}
\hline IES-R & $\mathbf{r}$ & 0.185 & - & - \\
& $\mathbf{p}$ & $\mathbf{0 . 0 1 6}$ & - & - \\
DASS-21 & $\mathbf{r}$ & 0.132 & 0.696 & - \\
& $\mathbf{p}$ & 0.085 & $<0.001$ & - \\
\multirow{2}{*}{ PRAQ-R } & $\mathbf{r}$ & 0.008 & 0.348 & 0.454 \\
& $\mathbf{p}$ & 0.920 & $<0.001$ & $<0.001$ \\
\hline
\end{tabular}

IES-R: Impact of events scale, PRAQ-R: Pregnancy-related anxiety questionnaire, DASS-21: Depression anxiety stress scale-21

that the COVID-19 pandemic generally causes negative psychological effects in pregnant women.

It has been found that younger age in pregnant women is associated with a higher rate of maternal psychological stress disorder caused by COVID-19 (16). Wu et al. (20) found that pregnant women under 35 years of age had a higher risk of depression and anxiety during the pandemic period. Dagklis et al. (21) found that pregnant women aged 35 years and over had a 1.1-fold higher risk of anxiety caused by COVID-19 compared to those under the age of 35 years. In the present study, the mean IES-R score, PRAQ-R score and DASS-21 stress score were found to be significantly higher in women under the age of 35 years. These findings show that younger pregnant women are significantly more affected by the psychology of the COVID-19 pandemic, and that these pregnant women have a higher risk for increase in anxiety, depression and stress levels.
It has been found that low education level in pregnant women is associated with a higher rate of maternal psychological stress disorder caused by COVID-19 (18). Durankuş and Aksu (19) found that pregnant women with more education years had a lower level of depression. However, we did not find any difference between education groups. Similarly, Dong et al. (22) reported that there was no relationship between educational status and anxiety.

It has been stated that low income in pregnant women is associated with a higher rate of maternal psychological stress disorder caused by COVID-19 (16). Wu et al. (20) found that pregnant women with middle income had a higher risk of depression and anxiety during the pandemic. In the present study, the PRAQ-R score was significantly higher in the lowest income group living on the minimum wage compared to the other groups. This has shown us that the COVID-19 pandemic has a more negative psychological effect, especially in pregnant women with low income.

We found that COVID-19 had a more negative effect on the generally high stress levels of pregnant women experiencing the first pregnancy, and that these pregnant women were particularly concerned about their pregnancies and their children to be born. However, it has been reported that COVID-19 causes more negative psychological effects in pregnant women with more children (19). Dagklis et al. (21) reported that those with higher number of pregnancies had a 1.2-fold higher risk of anxiety caused by COVID-19 compared to women with first pregnancy. Conversely, $\mathrm{Wu}$ et al. (20) found that women experiencing the first pregnancy had a higher risk of depression and anxiety during the pandemic. According to these findings, it can be thought that the main concern in pregnant women with a high number of children is the pregnancy itself and not the child to be born, but their present children.

It has been stated that there is no significant relationship between the level of knowledge about COVID-19 and depression level caused by COVID-19 in pregnant women (19). In the present study, those who said they had sufficient or fair knowledge about COVID-19 were found to be significantly lower than those who said they had little or moderate knowledge in all three scales. The fact that the anxiety and depression scores due to COVID-19 are significantly lower in pregnant women who think that they have more knowledge may suggest that the information will have a positive effect on the psychological mood. Additionally, the rate of pregnant women infected by COVID-19 in their family was $6.6 \%$. Although all scores were high in all of these cases, no statistical difference was 
Table 6. The mean scores according to the groups of concern about harm to the baby and the groups of anxiety not to get medical help

\begin{tabular}{|c|c|c|c|c|c|c|}
\hline & \multicolumn{6}{|c|}{ Groups of anxiety about harm to the baby } \\
\hline & None & A little & Moderate & Very much & Extreme & $\mathbf{p}$ \\
\hline IES-R total score & $6.8 \pm 6.5$ & $21.6 \pm 8.7$ & $23.7 \pm 11.1$ & $27.7 \pm 11$ & $36.8 \pm 10.4$ & $<0.001$ \\
\hline PRAQ-R total score & $17.4 \pm 7.8$ & $25.6 \pm 5.3$ & $25.8 \pm 5.3$ & $30.6 \pm 6.7$ & $33.2 \pm 8.6$ & $<0.001$ \\
\hline DASS-21 total score & $1.3 \pm 2.1$ & $7.5 \pm 6.7$ & $8.3 \pm 6$ & $11.6 \pm 8$ & $17.3 \pm 8.2$ & $<0.001$ \\
\hline DASS-21 depression & $0.3 \pm 0.7$ & $2.5 \pm 3.3$ & $2.5 \pm 2.2$ & $3.3 \pm 3.2$ & $4.6 \pm 2.6$ & 0.001 \\
\hline DASS-21 anxiety & $0.2 \pm 0.4$ & $1.7 \pm 2$ & $2.4 \pm 2.2$ & $3.4 \pm 2.3$ & $5.8 \pm 3.2$ & $<0.001$ \\
\hline \multirow[t]{3}{*}{ DASS-21 stress } & $0.8 \pm 1.8$ & $3.3 \pm 2.6$ & $3.4 \pm 2.6$ & $4.9 \pm 3.3$ & $6.9 \pm 3.6$ & $<0.001$ \\
\hline & \multicolumn{6}{|c|}{ Groups of anxiety about not getting medical help } \\
\hline & None & A little & Moderate & Very much & Extreme & $\mathbf{p}$ \\
\hline IES-R total score & $21 \pm 11.1$ & $27.1 \pm 9.2$ & $33.7 \pm 10.9$ & $30 \pm 0$ & $42.2 \pm 12.6$ & $<0.001$ \\
\hline PRAQ-R total score & $25.6 \pm 7.2$ & $30 \pm 6.5$ & $29.4 \pm 6.5$ & $40 \pm 0$ & $36 \pm 6.7$ & $<0.001$ \\
\hline DASS-21 total score & $7.5 \pm 5.9$ & $13.6 \pm 8.8$ & $12.7 \pm 9.3$ & $4 \pm 0$ & $17.2 \pm 9.1$ & $<0.001$ \\
\hline DASS-21 depression & $2.1 \pm 2$ & $4.3 \pm 3.6$ & $3.8 \pm 3.5$ & $0 \pm 0$ & $4.8 \pm 3$ & $<0.001$ \\
\hline DASS-21 anxiety & $2.1 \pm 2.1$ & $4 \pm 3$ & $3.9 \pm 3.1$ & $3 \pm 0$ & $5 \pm 3$ & $<0.001$ \\
\hline DASS-21 stress & $3.3 \pm 2.7$ & $5.3 \pm 3.7$ & $5 \pm 3.5$ & $1 \pm 0$ & $7.4 \pm 3.9$ & 0.001 \\
\hline
\end{tabular}

IES-R: Impact of events scale, PRAQ-R: Pregnancy-related anxiety questionnaire, DASS-21: Depression anxiety stress scale-21

observed. However, it was observed that this did not affect the overall depression, stress and anxiety scores.

Dong et al. (22), in their study with 156 pregnant women, found no significant correlation between week of pregnancy and level of depression caused by COVID-19. In another study, it was found that anxiety level increased in the later trimesters (21). In the present study, in the correlation analysis performed, gestational week was found to be significantly correlated only with the IES-R score. These findings may show that pregnant women whose births were approaching may have been affected more negatively by the COVID-19 pandemic compared to the scale of the effects of the events.

Wu et al. (20) found that pregnant women working fulltime have a higher risk of depression and anxiety during the pandemic. In the present study, there was no significant difference between the job groups in terms of scale scores. It may be more appropriate to evaluate the relationship of the job situation with the psychology of the COVID-19 pandemic together with the economic and social rights and socioeconomic status of pregnant women in each country.

In this study, it was observed that $35.1 \%$ of pregnant women had severe or very severe anxiety about harm to the baby due to COVID-19. Yang et al. (6) reported this rate as $7.8 \%$. Ravaldi et al. (23) reported the rate of patients with anxiety symptoms as $21.7 \%$. Corbett et al. (18) found that during the COVID-19 pandemic process, pregnant women experienced the most anxiety about their elderly relatives, children and unborn babies, respectively. Additionally, they found that pregnant women had least but still significant anxiety about their own health. Fakari and Simbar (24) also reported that pregnant women were most anxious about their relatives and unborn babies during the COVID-19 pandemic, and they determined that these pregnant women were hesitant to go to the hospital for controls. Studies show that, similar to our study, the proportion of pregnant women concerned about the health of their unborn babies is high $(17,23)$.

It was seen that the highest scores in the IES-R scale belonged to the rate of thinking about the pandemic. This finding shows that pregnant women are aware of that the COVID-19 pandemic disturbs them, they unintentionally think about this pandemic and try to avoid this thought. It was observed that the highest scores in the DASS-21 scale belong to unreasonable fears. This finding may indicate that COVID-19 causes a negligible but significant deterioration in mental health of pregnant women. In the PRAQ-R scale, it was observed that the highest scores were related to pain, birth and the health of the baby. These items do not appear to be directly related to the COVID-19 pandemic. Scale scores were found to be significantly correlated with each other in correlation analysis. This finding shows that the scales are in accordance with each other. 


\section{Study Limitations}

There were some limitations in the present study. Since the present study was planned on a cross-sectional and scale basis, the changes in the psychological states of pregnant women after pregnancy were not observed and evaluation could not be made on this issue.

\section{Conclusion}

The COVID-19 pandemic is deeply affecting the mental health of pregnant women, and pregnancy-specific anxiety changes seem to be caused by factors independent of pregnancy. This study is one of the few studies examining the psychological effects of the COVID-19 pandemic in pregnant women with scale data. It was determined that the pandemic had a negative effect on the depression, anxiety and stress levels of pregnant women, and this effect was higher especially in younger pregnant women and in those experiencing their first pregnancy.

\section{Ethics}

Ethics Committee Approval: Approval was obtained from the University of Medipol Ethics Committee for noninterventional clinical trials within our institution (date: 02.01.2020; number: 001212).

Informed Consent: It was made with the permission of the Ministry of Health (2020-05-19T13_03_28). Written informed consent was obtained from all participants.

Peer-review: Externally peer-reviewed.

\section{Authorship Contributions}

Concept: E.Ç.E., S.G.Ş., Design: E.Ç.E., S.G.Ş., Data Collection or Processing: E.Ç.E., Analysis or Interpretation: S.G.Ş., Drafting Manuscript: E.Ç.E., S.G.Ş., Final Approval and Accountability: E.Ç.E., Supervision: E.Ç.E., S.G.Ş.

Conflict of Interest: No conflict of interest was declared by the authors.

Financial Disclosure: The authors declared that this study received no financial support.

\section{References}

1. Becker M, Weinberger T, Chandy A, Schmukler S. Depression during pregnancy and postpartum. Curr Psychiatry Rep 2016;18(3):32.

2. Vigod SN, Wilson CA, Howard LM. Depression in pregnancy. BMJ 2016;352:i1547. doi: 10.1136/bmj.i1547.

3. Bayrampour H, Ali E, McNeil DA, Benzies K, MacQueen G, Tough S. Pregnancy-related anxiety: a concept analysis. Int J Nurs Stud 2016;55:115-130.
4. Mudra S, Göbel A, Barthel D, Hecher K, Schulte-Markwort M, Goletzke J, et al. Psychometric properties of the German version of the pregnancy-related anxiety questionnaire-revised 2 (PRAQ-R2) in the third trimester of pregnancy. BMC Pregnancy Childbirth 2019;19(1):242.

5. Brunet A, St-Hilaire A, Jehel L, King S. Validation of a French version of the impact of event scale-revised. Can J Psychiatry 2003;48(1):56-61.

6. Yang X, Song B, Wu A, Mo PKH, Di J, Wang Q, et al. Social, Cognitive, and eHealth Mechanisms of COVID-19-Related Lockdown and Mandatory Quarantine That Potentially Affect the Mental Health of Pregnant Women in China: Cross-Sectional Survey Study. J Med Internet Res 2021;23(1):e24495. doi: 10.2196/24495.

7. Barber CC, Steadman J. Distress levels in pregnant and matched nonpregnant women. Aust N Z J Obstet Gynaecol 2018;58(1):128-131.

8. Kotta S, Molangur U, Bipeta R, Ganesh R. A cross-sectional study of the psychosocial problems following abortion. Indian J Psychiatry 2018;60(2):217-223.

9. Asukai N, Kato H, Kawamura N, Kim Y, Yamamoto K, Kishimoto J, et al. Reliability and validity of the Japanese-language version of the impact of event scale-revised (IES-R-J): four studies of different traumatic events. J Nerv Ment Dis 2002;190(3):175-182.

10. Creamer M, Bell R, Failla S. Psychometric properties of the Impact of Event Scale - Revised. Behav Res Ther 2003;41(12):1489-1496.

11. Kawamura N, Kim Y, Asukai N. Suppression of cellular immunity in men with a past history of posttraumatic stress disorder. Am J Psychiatry 2001;158(3):484-486.

12. Oei TP, Sawang S, Goh YW, Mukhtar F. Using the Depression Anxiety Stress Scale 21 (DASS-21) across cultures. Int J Psychol 2013;48(6):1018-1029.

13. Aksoy Derya Y, Timur Tashan S, Duman M, Durgun Ozan Y. Turkish adaptation of the pregnancy-related anxiety questionnaire-revised 2: Validity and reliability study in multiparous and primiparous pregnancy. Midwifery 2018;62:61-68

14. Vázquez MB, Pereira B, Míguez MC. Psychometric properties of the spanish version of the Pregnancy Related Anxiety Questionnaire (PRAQ). Span J Psychol 2018;21:E64. doi: 10.1017/sjp.2018.67.

15. Kajdy A, Feduniw S, Ajdacka U, Modzelewski J, Baranowska B, Sys $\mathrm{D}$, et al. Risk factors for anxiety and depression among pregnant women during the COVID-19 pandemic: A web-based crosssectional survey. Medicine (Baltimore) 2020;99:e21279. doi: 10.1097/MD.0000000000021279.

16. Berthelot N, Lemieux R, Garon-Bissonnette J, Drouin-Maziade C, Martel É, Maziade M. Uptrend in distress and psychiatric symptomatology in pregnant women during the coronavirus disease 2019 pandemic. Acta Obstet Gynecol Scand 2020;99(7):848855.

17. Moyer CA, Compton SD, Kaselitz E, Muzik M. Pregnancy-related anxiety during COVID-19: a nationwide survey of 2740 pregnant women. Arch Womens Ment Health 2020;23(6):757-765.

18. Corbett GA, Milne SJ, Hehir MP, Lindow SW, O'connell MP. Health anxiety and behavioural changes of pregnant women during the COVID-19 pandemic. Eur J Obstet Gynecol Reprod Biol 2020;249:96-97.

19. Durankuş F, Aksu E. Effects of the COVID-19 pandemic on anxiety and depressive symptoms in pregnant women: a preliminary study. J Matern Fetal Neonatal Med 2020:1-7. doi: 10.1080/14767058.2020.1763946. Epub ahead of print. 
20. Wu Y, Zhang C, Liu H, Duan C, Li C, Fan J, et al. Perinatal depressive and anxiety symptoms of pregnant women along with COVID-19 outbreak in China. Am J Obstet Gynecol 2020;223(2):240.e1-240. e9. doi: 10.1016/j.ajog.2020.05.009.

21. Dagklis T, Tsakiridis I, Mamopoulos A, Athanasiadis A, Papazisis G. Anxiety During Pregnancy in the Era of the COVID-19 Pandemic. Lancet, 2020. (in press). (Available from: http://dx.doi.org/10.2139/ ssrn.3588542).

22. Dong H, Hu R, Lu C, Huang D, Cui D, Huang G, et al. Investigation on the mental health status of pregnant women in China during the Pandemic of COVID-19. Arch Gynecol Obstet 2021;303(2):463469.

23. Ravaldi C, Ricca V, Wilson A, Homer C, Vannacci A.Previous psychopathology predicted severe COVID-19 concern, anxiety, and PTSD symptoms in pregnant women during "lockdown" in Italy. Arch Womens Ment Health 2020;23(6):783-786.

24. Fakari FR, Simbar M. Coronavirus Pandemic and Worries during Pregnancy; a Letter to Editor. Arch Acad Emerg Med 2020;16;8(1):e21. https://pubmed.ncbi.nlm.nih.gov/32185371/ 